\author{
Veronica Arridu $u^{*}$, Arūnas Molis ${ }^{* *}$
}

The General Jonas Žemaitis Military Academy of Lithuania**

\title{
Alliance between Putin and European Far-Right: Where Does the Convergence of Interests Lead?
}

\begin{abstract}
The study traces the development occurred in the alliance between Putin's Russia and the European far-right parties since the European Parliamentary election held in May 2019. The article briefly summarizes the populist upsurge in Europe, exploring the reasons behind it. Consequently, the relations established between the political actors are outlined, starting with the concept of "sovereign democracy" to cover all the eventual points where the interests of the Kremlin match with those of the European far-right populists. The ultimate purpose of the study is to define three possible macro-scenarios for the alliance and, indirectly, for the European Union in the near term, concluding that even though the uprising of the populist parties has been somehow contained and the alliance has been widely exposed, the far-right still benefits from great success among public opinion. Furthermore, however ephemeral and transitory the collaboration between Putin and the populists may be, it has already laid the foundations for a more fruitful understanding. Russia's importance as an economic and political partner will grow as its friendly political forces do and their mutual sympathy will stand until there are reciprocal gains.
\end{abstract}

\section{Introduction}

Connections between Western populists and the Russian Federation are not completely new but recently the phenomenon increased so much that it captured the attention of the media and political analysts, especially in the light of the threats that populism is projecting all over Europe. The purpose of this article is to analyse the convergence of interest between populist parties in Europe and Putin's Russia. The work is built upon core research questions:

\footnotetext{
-Veronica Arridu is a business analyst at Crif s.p.a. Address for correspondence: Tumedei Street 40, 47121 Forlì, Italy; phone: +39 3921540716 e-mail: veronica.arridu@gmail.com

" Dr Arūnas Molis is a professor at Vytautas Magnus University, Faculty of Political Science and Diplomacy. Address for correspondence: V. Putvinskio str. 23-604, LT-44243, Kaunas, Lithuania; phone: +37037206704; e-mail: arunas.molis@vdu.lt

${ }^{* * *}$ This article has been written on order from the General Jonas Žemaitis Military Academy of Lithuania under Authorship Agreement No 8P-5 dated 10 December 2018.
}

DOI: 10.2478/lasr-2019-0006

(C) Veronica Arridu, Arūnas Molis, 2019

(C) Military Academy of Lithuania, 2019 
-What are the causes of the rise of populism within the EU borders?

- Where do the interests of populists and the Kremlin match?

- What are the likely scenarios for the alliance in the short term?

In order to properly analyse the recent developments, a very short timeframe has been taken into consideration, starting from the 2014 EP elections. The reason is twofold: first of all, that was the first time when EU populist parties achieved important results at the EU level (and, for some of them, for the first time at all). Secondly, from this date onwards the links between the populists and Putin's Russia became clearer than ever. Despite the importance of the topic, there is not yet any well-structured and comprehensive literature on the subject, mainly due to the proximity of those events. It is possible to retrieve remarkable studies, produced by think tanks: one of the most productive in this sense is the Hungarian Political Capital ${ }^{1}$, which analyses the relations between European far-right parties and the Russian Federation, proceeding case by case, giving a clear overview of the links Russia established in Europe, looking also at the paramilitary associations (in Slovakia, Poland, Austria and the Czech Republic). Marlene Laruelle, co-author of From Paris to Vladivostok, edited the book Eurasianism and the European far-right ${ }^{2}$ where, among others, there is a detailed article about the involvement of the EU far-right parties and the Russian Federation in the international monitoring mission, which provides a very interesting point of view regarding concrete strategic collaborations between the actors mentioned above.

In NATO's Baltic Problem ${ }^{3}$ the connection between Russia and the populist political actors in the Baltic region are treated as one of the main threats endangering the cohesion and, basically, the international strength of the North Atlantic Alliance, especially in the light of the shift of the US foreign policy under the Trump presidency. It is quite easy to find that the main reasons for the Russian interests in the region transcend from the Russian-speaking minority living there, encompassing considerable historic, economic and energy interests: for these reasons, after the annexation of Crimea, many political commentators argued that the Baltics were to be considered the next target and the fear has been fuelled by the increasing Russian information warfare in the region. The issue of the Russian minority in Estonia, Latvia and Lithuania

\footnotetext{
${ }^{1}$ Weidinger, B., Schmid, F., \& Krekó, P. (2017). Russian Connections of the Austrian Far-Right. Budapest: Political Capital.

${ }^{2}$ Laruelle, M., Gyori, L., Krekó, P., Haller, D., \& Reichstadt, R. (2015). From Paris to Vladivostok. The Kremlin Connections of the French Far-Right. Budapest: Political Capital.

${ }^{3}$ Ubriaco, J. (2017). NATO’s Baltic Problem: How Populism, Russia, and the Baltic Can Fracture NATO.

Harvard International Review 38(1): p. 13.
} 
has substantially affected the debate of national security, referring to the assertions of the Kremlin, willing to protect each Russian minority living abroad, and the disinformation campaigns of which they are the main target audience. The geographical proximity and the common Soviet past (when the three Baltic republics were invaded by the Red Army and annexed to the Soviet Union until the 1990s) make even more worrisome the recent successes of the populist parties and their relation with Putin's Russia, and are pivotal for an overall understanding of the developments of Russian links to the European populists.

The principal source of information remains the media and the problem is the opposite. It is really hard to distinguish the most relevant materials because of the enormous scale of interviews, articles, commentaries and documentaries available. In order to establish a certain structural order it is necessary to follow a clear criterion. Russian state-sponsored media outlets offer an interesting insight into the Kremlin's propaganda: they provide the big picture of Moscow propaganda and, giving a huge public media space to far-right representatives, they report (in many case overstating) their declarations and statements. As far as the official media are concerned, they have been chosen according to a criterion of reliability.

\section{Tendencies in Europe: Reasons for Populist Upsurge}

Two main groups of factors can be identified in order to find out what has caused the populist upsurge in the last decade. The demand-side factors are mainly built on the three grievances on which the populist narrative is based: the scarcity of resources, the perception of outgroups as dangerous to the national identity, and the difficulties encountered by the lower classes to adjust themselves to a globalized world ${ }^{4}$. The second group includes all those considered as the supply-side factors or, in other words, all those exogenous factors such as electoral rules, the nature of the party competition and the impact of the media ${ }^{5}$. The easier scapegoat identified has been the economic crisis of 2008. Economic recession hit the eurozone harshly, revealing the imbalances between the north and the south of Europe. The lack of an effective central response led to the application of unpopular austerity policies: the EU population

\footnotetext{
${ }^{4}$ Golder, M. (2016). Far Right Parties in Europe. Annual Review of Political Science 19: pp. 477-497 ${ }^{5}$ Muis, J., \& Immerzeel, T. (2017). Causes and Consequences of the Rise of Populist Radical Right Parties and Movements in Europe. Current Sociology 65(6): pp. 909-930.
} 
started gradually to blame the same EU for what was happening. The political elites, after promising a sort of "European dream", were now asking for sacrifices in the form of austerity, supervision of banking and coordination of fiscal policy. Some analysts assume that the falling political trust at both the EU and the national level has been the fortune of the populist parties. The EU ceased to be the solution and became the problem, together with the political establishment that created it, perceived increasingly distant and unaccountable. Apparently, "the euro crisis and the wider economic problems have revealed the cracks in the House of Europe" . Another important aspect to take into consideration is the idea of cultural loss, which is the root of far-right narrative: multiculturalism and European integration are condemned as some of the causes of the immigration waves, and the mismanagement of the latter has to be blamed for undermining the respective national identities in each of the host states.

The new wave of populism in the West is a very complicated phenomenon: the various national parties that emerged in the aftermath of the 2008 crisis do not belong to the same ideological background. They appear instead highly variegated in ideology: Eurosceptic and pro-Russian parties in Europe are a mix of far-left parties (like Syriza and Podemos), far-right parties and even openly neo-Nazi ones (like Golden Dawn). Some of them do not belong to any political groups, claiming to be independent and anti-establishment (as in the case of the Italian Five Star Movement). It can be said that, instead of having common goals, they are united by common enemies: their strong opposition to the EU, perceived as a threat to state sovereignty, and NATO, considered as tool through which Washington exerts its pressure on Europe, made Putin their natural ally in the international arena. From the north of Europe to the south, Putin's appeal brought him unexpected and increasingly important strategic allies. As reported by the American Enterprise Institute, "populism's simultaneous resurgence across Europe and the Kremlin's efforts to assert its dominance in the post-Soviet space belie any illusion that may have once existed about the inevitable triumph of democratic capitalism in Europe or about Europe as whole and free"7.

The European elections of 25 May 2014, where the populists achieved 212 out of 751 seats in the parliament, ${ }^{8}$ was just the beginning of the populist uprising. In Austria, Norbert Hofer (the FPÖ candidate) almost won the

\footnotetext{
${ }^{6}$ Marshall, T. (2015). Prisoners of Geography: Ten Maps That Tell You Everything You Need to Know About Global Politics. London: Elliott and Thompson.

${ }^{7}$ Rohac, D., Zgut, E., \& Györi, L. (2017). Populism in Europe and its Russian Love Affair. Washington, DC: American Enterprise Institute.

${ }^{8}$ Treib, O. (2014). The Voter says No, but Nobody Listens: Causes and Consequences of the Eurosceptic Vote in the 2014 European Elections. Journal of European Public Policy, 10(21), pp. 1541-1554.
} 
presidential elections in April 2016. At the legislative elections held in Austria in October 2017, Hofer's party affirmed itself as the third political force in the country. As much as FPÖ gained power, as much Moscow courted its members: in December 2016, Strache (the FPÖ leader) signed a cooperation agreement with United Russia, which provides for "exchange experiences", "[to] send delegations to each other", and inform each other about domestic politics. Both parties are committed to "educating youth to a spirit of patriotism and a love of work" . A key actor in the establishment of such good relations has been the oligarch Konstantin Malofeev, chairman of the Saint Basil the Great Charitable Foundation and founder of the Marshall Capital. In 2007 he hosted a meeting in Vienna: among the invited were Strache, Gudenus, Marion Maréchal-Le Pen and Volen Siderov. Malofeev works as an efficient bridge between Austria and Russia: he released several interviews to Austrian magazines, asserting and explaining to what extent the Kremlin and the FPÖ views match: that business ties and foreign policy are less important than the common Christian values, mainly referring to the anti-LGBT position.

In southern Europe the combination of austerity policies and migration flows paved the way for the populist allure to grow multifaced and manifold. Perhaps Greece is the most iconic example: after the January 2015 elections, one of the first moves of the Syriza party's newly appointed government was to call a referendum asking whether Greece should accept the agreement submitted by the European Commission, the European Central Bank and the IMF to the Eurogroup. The ruling party, together with ANEL and Golden Dawn, supported the "No" vote, which won with $61 \%$. The Greek issue is far from being solved: despite Tsipras eventually complying with the demands from Brussels, Greece is one of the weakest countries of the EU, and susceptible to foreign influences.

Italy is another hot spot within the eurozone: the political instability of the country corroded the trust of the population in both national and European institutions, blamed for the economic constraints and the austerity policy. The migration flows in the south of the country pretty much caused a humanitarian crisis, fuelling public opinion against Europe. These are the main points highlighted by the parties that won the election in March: the Five Star Movement and the League. The then Minister of Interior, Salvini, immediately spoke harshly about migration and the importance of close ties with Russia. During the short life of the "yellow-green" government, its nationalist policies isolated

\footnotetext{
${ }_{9}^{9}$ Weidinger, B., Schmid, F., \& Krekó, P. (2017). Russian Connections of the Austrian Far-Right. Budapest: Political Capital.
} 
Italy in the EU: the worsening of the relationships with the major European countries (such as France) pushed Rome towards long-standing "illiberal democracies", such as Putin's Russia.

From November 2016 Rumen Radev has been President of Bulgaria, after an electoral campaign that was characterized by the debate concerning the national foreign policy. While the candidate of GERB endorsed the EU policy, Radev, the independent candidate backed by the Socialists, deemed the sanctions as a dangerous threat against Bulgarian national interest. Considering the strong historical ties between Russia and Bulgaria, with this move he was able to secure the vote of the pro-Russian electorate and the support of the pro-Russian parties within the Bulgarian political scenario ${ }^{10}$. When the newly appointed president claimed that "a Russian flag was already flying over Crimea", the EU worried about the future position over sanctions and the relation with Russia, warily looking at the political developments in Bulgaria: despite Radev confirming his commitment to the EU and NATO, the idea of a member country openly siding with the Russian Federation would seriously endanger the already weak EU common foreign policy.

In Prague, the Eurosceptic Andrej Babiš won the elections with about $30 \%$ of the vote and managed to establish a "minority government", with a fragile coalition of the ANO 2011 party and independents. A strong pro-Russian rhetoric has become popular recently, also supported by the re-elected President Miloš Zeman who, as reported by the New York Times, "has strengthen the country's ties with Russia and has courted China" ${ }^{11}$. Zeman's conservative political programme fascinated the Kremlin so much that his speeches are proudly reported in the main Russian media outlets, together with those of Martin Nejedlý, who financed Zeman's electoral campaign and is an executive in the Czech branch of Lukoil ${ }^{12}$ : they blame the EU for imposing the sanctions because of the consequences for the same EU exporters, highlighting in the meanwhile their futility ${ }^{13}$ and their unfairness, the latter justified by the fact that the Czech president, "take[s] seriously the statement of [Russian] foreign minister Sergei Lavrov that there are no Russian troops [there]"14. Despite the Slovak Prime Minister Robert Fico stating that Slovakia remains the only

\footnotetext{
${ }^{10}$ Dąborowski, T. (2016). President Radev: A Time of Political Changes in Bulgaria. Osrodek Studiow Wschodnich im. Marka Karpia.

${ }^{11}$ Santora, M. Czech Republic Re-elects Milos Zeman, Populist Leader and Foe of Migrants. The New York Times, 27 January 2018.

${ }^{12}$ Ereli, A. Is the Czech Republic Falling Under Putin's Shadow? Foreign Policy, 10 October 2017.

${ }^{13}$ Vejvodová, P., Janda, J., \& Vichová, V. (2017). The Russian Connections of Far-Right and Paramilitary Organizations in the Czech Republic. Budapest: Political Capital.

${ }^{14}$ Janda, J. Czech President is Russia's Trojan Horse. EU Observer, 10 June 2016.
} 
pro-European country within the V4 group, Brussels is getting some mixed messages from Bratislava. The Slovak National Party, ruled by Andrej Danko (President of the Slovak Parliament) has a long history of ties with Russia, meaning that now it pushes against the sanctions, because "we are historically predestined for cooperation. We are tied by materials. Whoever said that Slovakia shouldn't deepen its relationship with Russia is wrong"15. In Poland, populism has its roots on the strong Polish Catholic traditions, together with calls for a change at the EU level. Furthermore, the ruling populist Law and Justice party (PiS) benefited from the refugee crisis, adopting "an uncompromising anti-immigration position, notwithstanding the fact that Poland, which is among the most ethnically homogeneous countries in the world, has not seen any significant migration inflows" ${ }^{16}$. In Hungary, the premier Orbán started building fences at the border with Serbia to stop the migration flows, backed by Jobbik, now the second strongest party in Hungary. As in Poland, Eurosceptic parties represent the ruling class: the main difference is that while Poland still perceives Russia as a threat, Budapest is striving for a preferential relationship with Moscow. The peculiarity of the post-communist transition left a legacy of weak civil society and fragile democratic structures, adding a geopolitical nuance to the European far-right parties' family.

Lithuania is the Baltic country with the smallest Russian minority: for this reason the Kremlin had to refer to proxies in order to win some kind of influence within the national political debate. The Electoral Action of Poles in Lithuania - Christian Families Alliance (EAPL-CFA), led by Tomaševski, fulfils that requirement, targeting both the Russian and the Polish minority (much larger than any other in the territory) and this represents a very interesting case for analysis. The position of the party on issues such as the Ukraine's Maidan revolution is appealing for the Russian minority (which in Lithuania corresponds to the $6 \%$ of the population), to such an extent that a political alliance with the Alliance of Russians seemed the most natural ${ }^{17}$. In line with the other populist parties, EAPL endorses the Russian narrative: Crimea has been compared to Kosovo, sanctions are deemed dangerous and pernicious, and EAPI management actively collaborates with Moscow-backed media outlets, such as the Baltic World magazine. Emblematic of the pro-Russian attitude of Tomaszewksi was his use of the St George's ribbon, symbol of the Soviet

\footnotetext{
${ }^{15}$ The Slovak Spectator, Parliament Speaker says He Feels Nostalgic about Totalitarian Regime, 30 June 2017.

${ }^{16}$ Rohac, D., Zgut, E., \& Győri, L. (2017). Populism in Europe and its Russian Love Affair. Washington, DC: American Enterprise Institute.

${ }^{17}$ Cichowlas, O. Lithuania is Arming Itself Against a Feared. The Nation Thailand, 28 March 2015.
} 
victory against Nazi Germany, harshly criticized for its political meaning. In Latvia, the division between ethnic Latvians and Russian speakers is more accentuated than in Lithuania. The Russian speakers are almost one-third of the population, being the largest Russian-speaking minority within the EU. So, considering the numbers, it is not a surprise that the Russian minority has had parliamentary representations since the 1990s. Harmony shines among the others because of the close contact with the Russian Motherland: in 2009, Urbanovičs and Boris Gryzlov signed a cooperation agreement within the two parties $^{18}$. It has to be noted that opposition's social democratic party Harmony developed into one of the strongest political forces in Latvia - not only did it gain the most votes in the last two parliamentary elections, but it has also been in charge of the capital city of Riga (the major business, political and cultural hub of Latvia). This political force has an official cooperation agreement with the United Russia and it is known to have unofficial party and individual level ties to the Russian government: according to some allegations, it was Russia that sponsored and financed his electoral campaign in 2009, while the country has been used "like a trampoline, to send their people to Europe and the US. Russian spies with Latvian passports can travel undetected across the $\mathrm{EU}^{19}$. In November 2016 Jüri Ratas was nominated Prime Minister of Estonia: he belongs to the Centre Party, which over the years cultivated very interesting relations with Putin's Russia. The former chairman of the party was Edgar Savisaar, former mayor of Tallinn, who hit the headlines when the Estonian Security Services accused him of taking $€ 1.5$ million from the oligarch Vladimir Yakunin, President of the Russian Railways and member of Putin's inner circle. Savisaar was also the architect of a cooperation agreement with United Russia: despite the financial benefits received from this agreement, it was also detrimental for his political career, considering that in order to become the ruling party an escalation was needed, with a consequent change in the party's management.

\footnotetext{
${ }^{18}$ McGuinness, D. 'Russian Agent' Row hits Latvian Elections. BBC 10 April 2014.

${ }^{19}$ Harding, L. Latvia: Russia's Playground for Business, Politics - and Crime. The Guardian, 23 January 2013.
} 


\section{Where do the interests of the Kremlin and the European populist match?}

The proposal of a geopolitical alternative is one of the key features of Putinism. Vladimir Surkov coined the term "sovereign democracy" to define the political path Putin was pursuing, deepening the distance from the Western liberal democracies: internally, the centralization of the political power is presented as necessary to grant stability to the nation state while in foreign policy, the focus was on protecting the country from foreign meddling. It is undeniable that Putin invested in promoting such ideas and images, gaining the favours of the far-right populists, who harshly criticize the governmental interconnections and the lack of national sovereignty within the EU. All the appealing features of the sovereign democracy are strictly interconnected to the idea of centralization of power: the state (and not the people) is what should be preserved, and adopting a strictly nationalist line is the better way to accomplish the ambitious goal. Anti-globalism is strictly followed by antiWesternism: who else is to be blamed but the EU and the USA for it?

The investments in media agencies charged of spreading the image of Russia as a conservative fortress, in opposition to a decadent West, ${ }^{20}$ are rising exponentially. Even long before the Ukrainian crisis, Russia Today and the Voice of Russia, followed later by Sputnik and Ria Novosti (to mention just a few) covered the weaknesses within the European Union in detail, emphasizing the moral decay, multiculturalism, the euro and the loss of sovereignty within the eurozone. Their special guests were politicians such as Marine Le Pen, Mateusz Piskorski, Farage, Salvini and most of all their European colleagues, who were eager to use the international media platform offered to spread their anti-Western stance ${ }^{21}$. According to this narrative, the EU, the antidemocratic monster, was anything but a US puppet in foreign policy affairs and the European elites opened the gates to the "infertile and genderless" liberalism, multiculturalism and globalization, tracing the path towards a "chaotic darkness". The West is portrayed as in deep moral decay because of the denial of its Christian roots: situations such as immigration waves seem widely accepted at the political level, if not welcoming, as in the case of Angela Merkel who opened the bor-

\footnotetext{
${ }^{20}$ Van Herpen, M. H. (2013). Putinism: The Slow Rise of a Radical Right Regime in Russia. London: Palgrave Macmillan.

${ }^{21}$ Shekhovtsov A. (2015). Bringing the Rebels: European Far Right soldiers of Russian Propaganda. London: Legatum Institute Transitions Forum.
} 
ders to almost one million migrants from Syria ${ }^{22}$. By promoting those ideals, it was easy for Putin (leader of a nuclear power and economic giant) to become the "leader of the conservative world", financing and supporting his peers ${ }^{23}$. Some parts of Western society have started to be concerned over this decay and increasingly praise Putin as the real defender of Christian European values in general, and of Orthodoxy in the specificity of Bulgaria and Greece. The "anti-propaganda" law adopted by Russia, framed in the context of returning to traditional values in order to protect the traditional family and Russianness against the LGBT lobbies, is highly appreciated both by the orthodox and in far-right political circles, to the point that in some cases similar draft laws have been presented in their respective national parliaments. Furthermore, the strong anti-EU and anti-NATO stances of Russian foreign policy are increasingly appealing for those who advocate a Europe of sovereign states.

On 19 September 2013 Putin explained the new conservative direction that the Russian Federation was undertaking under his command, deepening the differences with the Western world: "it is impossible to move forward without spiritual, cultural and national self-determination", and also "we can see how many of the Euro-Atlantic countries are actually rejecting their roots, including the Christian values that constitute the basis of Western civilization. They are denying moral principles and all traditional identities"24. What was pivotal in appointing Putin as defender of Christianity and Western values has been the Islamic terrorism: when the Western countries where unable to manage the immigration wave coming from a destroyed and a Middle East at war, the Russian intervention in Syria confirmed the position of Putin as a leader for the conservative world. According to the narrative proposed by the state-controlled media, and then repeated in Europe by the Kremlin Trojan horses, while the USA and the EU destabilized the Middle East, fomenting the Arab Spring and creating social unrest, Moscow was the only actor effectively involved in defeating ISIS. Putin is doing it in order to promote a sort of conservatism 2.0, which has become a "brand" of Russia abroad and apparently, it has been successfully purchased in the West: while worsening the relationship with the mainstream parties, it attracted those at the fringes of the political spectrum. This for Putin means prestige, a more divided and, consequently,

\footnotetext{
${ }^{22}$ Yohannes, M. Angela Merkel Welcomes Refugees to Germany Despite Rising Anti-Immigrant Movement. The Washington Times, 10 September 2015.

${ }^{23}$ Foer, F. It's Putin’s World. The Atlantic, March 2017. Retrieved from https://www.theatlantic.com/magazine/archive/2017/03/its-putins-world/513848/

${ }^{24}$ Putin, V. V. Broadcast: Vladimir Putin's Speech at the Valdai Club's Plenary Meeting, 19 September 2013. https://www.youtube.com/watch?v=-PtsodE-ZkY
} 
easy to manipulate Europe: divide et impera has become the new guideline of Moscow's foreign policy. For Western populist parties, Russia represents the model they advocate for their respective countries and, speaking about foreign policy, their natural ally.

The national sovereignty issue ignites the Italian political debate: $\mathrm{Pu}$ tin is praised as a strong defender of the nation state, against the increasing menace represented by globalism. Pro-Russian stances deeply influenced the foreign policy line of League: when the former Italian government decided to take part in a NATO Enhanced Forward Presence battlegroup, which took place in Latvia, Matteo Salvini alarmingly accused NATO of playing "a very dangerous game by moving 4,000 troops towards Russia's border" 25 . In Hungary, the Prime Minister Orbán is very keen on Putin, with whom he shares the same nationalistic and revanchist goals. The far-right party Jobbik is also very popular in the country, and it is deeply interrelated with Moscow: emblematic of this relation is the case of Béla Kovács (renamed sarcastically KGBela), accused of spying for Russia. Greece and Bulgaria represent special cases: Ataka and Golden Dawn see Russia as their natural ally because of the common cultural heritage represented by the Orthodox faith. Their leaders repeatedly travelled to Moscow, where talks about energy security, foreign policy orientation and religious bonds took place with Russian high-ranking officials. In May 2014, Golden Dawn went one step further, welcoming the creation of the Eurasian Economic Union and expressing the desire to join it. Meanwhile, in Bulgaria Volen Siderov's opposition got as far as to threaten to quit his support to the government and, in this way, put it down. Oresharski had to make some concessions: even though he refused to veto the sanctions, he called at the EU level to lift the economic sanctions. It is noteworthy that, through this alliance, they can promote an alternative to the liberal order internationally.

Besides these unofficial meetings and speeches, a clear political structure has been established with the aim of enforcing the "unholy alliance". One of the most meaningful ones is the International Russian Conservative Forum, which presents itself as a platform aimed at promoting the establishment of a common constant-acting Russian-European conservative elite group uniting the political, industrial and religious elites in Russia and Europe. It functions as a political platform where the participants can work on a new concept of development, in opposition to the transnationalism and liberal ideology that have taken root in the West. They discuss ways in which it would be possible

\footnotetext{
${ }^{25}$ Polyakova, A., Kounalakis, M. K. A., Klapsis, A., Germani, L. S., Iacoboni, J., de Borja Lasheras, F., \& de Pedro, N. (2017). The Kremlin Trojan Horses 2.0. Washington, DC: The Atlantic Council.
} 
to implement the "spiritual and business-related connections" between Europe and Russia, finding attainable solutions to the ongoing instabilities. The participants include members from Forza Nuova, the Danish People's Party, British Unity, Ataka and Golden Dawn are present, as well as the leader of the Alliance for Peace and Freedom, Roberto Fiore and the Belgian Kris Roman, representative of the Euro-Rus organization.

Putin was able to rise as the champion of traditional values but was undermining the individual rights in the process. Furthermore, the Orthodox Church, divided in regional patriarchates, sees Moscow as its guide and, being sponsored by the Patriarch Kirill, Putin strengthened the connections with Golden Dawn and Ataka. The enhancement of "soft power" strategies was, from a Russian perspective, merely pragmatic: assuming they realize the dream to dismantle the EU, Putin would solve one of his most bothersome domestic problems. Aside from the ideological divergences, the EU represents a much more pragmatic threat: in the tug-of-war that international relations became, the supranational organizations such as NATO and the EU would remain stronger and mightier than a single nation, no matter whether that is a great power or a regional one. For this reason, Russia hardly tried to establish bilateral relations, customizing its approach according to the different historical and political backgrounds of the different countries. The fact that within the supranational organizations there is a percentage of Putin's "Trojan horses" safeguards his interests to a certain degree: the populist parties endorsed by Moscow are openly anti-establishment and, analysing their voting patterns, what catches the eye is the correspondence between their agenda and Russian interests which are, anyway, variegated.

The presence of a significant number of supporters who see Putin as a model and look forward to replicating the Russian model within their own borders, had given him international legitimacy and it keeps enhancing his popularity back home. The Russian electorate enjoys seeing how much his leader is appreciated and praised abroad. One of the most infamous examples is the media fuss around the LGBT antipropaganda law edited by the Russian Duma, which forbids the diffusion of "homonormativity" materials. By basically banning any reference from civil society of anything vaguely homosexual, Putin has been widely condemned by the international community but meanwhile, a broad cross-section of the Russian population was delighted with it. The traditional family and all the values related to it were endangered by the LGBT lobbies and by the distortion of Western liberalism and consumerism: to say it in Chauprade's words, the alternative order proposed by Russia is root- 
ed in what were Europeans' natural attachments (family, nations and divinity), rejecting the technocratic elites and the financial oligarchies.

The Russian intervention in Syria confirmed that Putin was the proper leader for the conservative world: it was the first time after the Soviet invasion of Afghanistan that Russia was meddling so loudly and openly out of its comfort zone. According to the narrative proposed by the state-controlled media, while the USA and EU destabilized the Middle East, the Russian Federation was the only actor interested in defeating ISIS. When Putin officially started the military campaign in September 2015 he had two things in mind: first, the victory was necessary in order to boost the reputation of the Russian Federation internationally, making it the political actor without whom it would be impossible to reach an agreement between the parties involved (President Assad, backed by Putin and his opponents). In addition, it has to be said that Moscow cared too much about the bases in Tartus and Latakia to risk losing them, because of repeating the catastrophe in Libya.

Russia represents the model they advocate for their respective countries and, speaking about foreign policy, it is their natural ally. Salvini, Le Pen, Farage and even Trump spoke about a future alliance with Putin, albeit the foreign policy of the EU and NATO are completely at odds with Russia's desired world order. From a Russian perspective, they are a way to destabilize Western countries without firing a single shot: this kind of soft power has been mastered by Russian politicians since the time of the USSR. Are we witnessing the creation of a "Putintern"? ${ }^{26}$ Alexander Morozov confirms in this statement:

Putin is creating a new COMINTERN. This is [...] the maximum Putinization of the world. The COMINTERN was a complex system that worked with ideologically sympathetic intellectuals and politicians. What we are seeing now is not an attempt to restore the past, but the creation of an entirely new hegemony ${ }^{27}$.

The voting patterns of the major populist parties within their national borders and within the EU institutions are unanimous in defending Russian interests. Their stances against sanctions were motivated to their electorate as necessary in order to save the national economy: since the Russian Federation is one of the most important economic partners of many EU Member States, the sanctions were depicted as unnecessary, unfair and ineffective measures employed to the detriment of the Russian people and in the interest of the EU. Supporting Russia in this issue trying to attract popular support can go so far as to endanger the stability of a national government, as in the above-mentio-

\footnotetext{
${ }^{26}$ Zhavoronkov, S. Putintern: A View from Russia. Intersection, 2 September 2015.

${ }^{27}$ Morozov, A. Новый Коминтерн. Colta, 10 December 2013.
} 
ned case of Bulgaria. The importance of this episode lies not so much in its practical consequences as in its geopolitical implications: it shows how much further Russia has gone in influencing decision-making processes in foreign governments and opens up a whole series of related issues. What could happen in the next few years, now that a growth of pro-Russian populist movements in Europe is taking place?

In order to provide a more accurate picture of the issue, the fact that Russia is one of the major economic partner of the EU for what concern several core sectors of the European economy must also be taken into account. One of the most debated is the energy sector, bearing in mind its repercussions on the wider issue of national security. Numerous attempts to bypass Russia as an energy partner in order to safeguard European energy security have been pursued, placing an emphasis on the risk inherent in the monopoly on the energy market exercised by unreliable trading partners, such as Gazprom. Orienting the energy policies of populist parties towards Russia has perhaps been one of the greatest successes achieved by the Kremlin: in the competition between Nabucco and South Stream, Hungary unconditionally backed the Gazprom project, proposing a draft resolution to the National Assembly of Hungary where, inter alia, the EU and the USA were blamed for exerting excessive pressure over all those countries involved in the project, completely careless of the countries' own interests (Jobbik). In Bulgaria, the South Stream debate was responsible for the resignation of Borisov and the consequent establishment of a coalition government where the quorum was granted by the Ataka party. The newly appointed president, Oresharski, found himself in the middle of an arm wrestling match between the EU and Moscow: the EU position became even harder after the annexation of Crimea, threatening Sofia to cut regional development funds in the case the government would persist on its intention to sign a deal with important violation to the EU Energy regulation $^{28}$. Eventually Putin dismissed the project, but not without blaming the $\mathrm{EU}$ and the US for the failure.

\section{Scenarios for the Russia-EU future}

Despite the sympathy between Russia and the rising populists, the EURussia relations are increasingly worsening. The friction started in 2014, after

\footnotetext{
${ }^{28}$ Yardley, J., \& Becker, J. How Putin Forged a Pipeline Deal That Derailed. The New York Times, 30 December 2014.
} 
the hybrid war in Ukraine, and nowadays is worsening, due to the continued Russian meddling in the Western democratic procedure. The latest scandals involving MEPs in Italy, Austria and Hungary are a good example of this trend. The following macro-scenarios are built in order to cover all the possible developments in the EU-Russia relations, considering the pivotal variable represented by the far-right populist parties. There are three most likely scenarios:

- suboptimal scenario, named Cold War 2.0;

- optimal scenario;

- medium scenario or balance of weaknesses.

\subsection{Cold War 2.0.}

According to the premises, in the worst-case scenario the Russian neoimperialist approach proves itself to be an efficient one. Domestically, the centralization of power in the hands of newly re-appointed President Putin is stronger than ever, proving to the ruling class that the turn taken in the third presidential term is the winning move. The investments in organizations such as Rossotrudnichestvo create the perfect grounds for the claims of the Russian minorities abroad: restoring Russian velikoderzhavnost would grant Putin favours at home and abroad, among the ultra-nationalist circles. There is no attempt to improve the economic structure of the country: "what seems more intriguing is the fact that this stagnation (being, in fact, the essence of Putin's much-vaunted stability), is welcomed by the majority of Russians who have been successfully indoctrinated by Putin's propaganda"29. The energy sector has proved itself to be insufficient in generating the budget necessary to drive the country and the economic stagnation is reflected in the political scene. As the political power is kept in the hands of the president and his circle, the economy is highly nationalized: stricter control is going to be applied to business, continuing the nationalization of private companies or their dismemberment, as in the case of Yukos.

In the EU, the populist parties keep on achieving political successes: in the upcoming European elections (May 2019) there are considerable possibilities that they are going to obtain the majority in the parliament. For Moscow, it would be incredibly easy to overcome the previous animosity with Western leaders: populist parties are in favour of the aggressive Russian policies, as

\footnotetext{
${ }^{29}$ Baev, P. K., Gabuev, A., Greene, S. A., Gressel, G. C., Inozemtsev, V., Lipman, M., . . Zhuchkova, Y. (2016). Russian Future: Horizon 2025. Paris: EU Institute for Security Studies.
} 
widely stated by their representatives. They perceive the Kremlin as a valid geopolitical alternative to the US-led world. Furthermore, Washington seems to be no longer interested in overseas affairs, considered a waste of money and resources. The transatlantic alliance is not a priority anymore and the entire set of alliances and treaties has to be customized to the current necessities of the member states: Trump has never kept secret his scepticism about the organization that, according to him, is funded by the US in order to protect self-sufficient states ${ }^{30}$.

Politically, a wide range of national interests obstruct an effective common approach, and the EU institution became increasingly engaged in mediating among Member States and rivalling political agendas. The absence of cohesion within the EU and NATO undermines the same international institutions which has granted peace and prosperity since the aftermath of the Second World War. Suddenly, the Eurasian Union becomes a feasible alternative to the old-fashioned institutions that did not fulfil their promises. The European countries which have already implemented their connections with Russia, are going to establish preferential agreements in energy and trade: the Russian big-brother attitude is projected "from Lisbon to Vladivostok". In this worrisome scenario, the Baltic States see their worst nightmare became true: the memories of the occupation of the Soviet Army are still vivid in the three countries. In order to avoid the Ukrainian destiny, they can only start shifting their attitude towards Russia: the Russian minorities in the Baltics should feel at home if they want to avoid a Crimean-fashion hybrid warfare.

\subsection{Optimal scenario}

The optimal scenario sees the recovery of the liberal democracies in the West. Despite the rise of the populist parties, the democratic forces that lie at the root of the European Union and NATO are able to lift public opinion's awareness on the threat they are facing. The risk of an ultra-conservative deterioration is solved through a path of institutional reforms: an efficient integration of the migrants and a developing economy are the best way to achieve the cohesion that has been lacking in the past ten years. Europe's biggest problems must be countered by common policies, thus undermining the attractiveness of populist parties for the electorate. Given the irresponsible policies those parties are pursuing in the countries where they have taken power, it is reasonable

${ }^{30}$ Krastev, I. Sorry, NATO. Trump Doesn't Believe in Allies. The New York Times, 11 July 2018. 
to assume that in the medium term this could be an advantage for democratic parties in the run-up to the elections. If democratic parties are able to modernize and move closer to their electorates, without losing sight of a broader project of international cohesion and unity, they will be able to strengthen the European project after this period of crisis. The idea of strengthening the European project goes hand in hand with the adoption of EU external policies: the EU must relate to the outside world as a single bloc, in order to exercise its full potential.

Assuming that the above conditions are met, Russia is increasingly isolated in the international scenario: Putin is losing all his international allies and the few remaining, like Assad, are well-known dictators. Sovereign democracy proves itself to be unsuccessful: the democratic wave that invested the postSoviet space years ago with the colour revolutions eventually reached Russia as well. The ongoing sanctions paralyse the economy, while the implementation of a renewed energy policy in the EU decreases drastically the power exerted by Gazprom. Having undermined the monopoly of Gazprom in the European market, the Russian economy is no longer able to maintain the onerous expenses that Putin's government has engaged to sustain his irresponsible foreign policy. As a result of the economic stagnation, public opinion has distanced itself from a ruling class that is indifferent to the factual reality in which the country finds itself, making it possible to form an organized opposition. As in the aftermath of the Cold War, Russia itself can be framed within a cooperative environment: the renewed friendly relations will lead to "strong bilateral and regional political dialogue as well as various issue-specific institutional platforms guarantee and foster deep and meaningful relations". Russia, being part of the European context and thanks to the democratic movements within it, can try to overcome the backwardness of its political structure, engaging a process of democratization and modernization. At some point, the liberalization may result in talks about an EU-Russian market.

\subsection{Medium scenario: the balance of weaknesses}

The most likely development in the medium term can be called a "balance of weaknesses": Europe is struggling with its internal issues. The economic crisis is not yet overcome and populist parties are in the government in some important states, while in others they are part of the ruling coalition ${ }^{31}$. Their

\footnotetext{
${ }^{31}$ Utkin, S., \& Harter, S. (2016). The Limbo. In: Monika Sus \& Franziska Pfeifer (Eds.) European Union in the World 2025: Scenarios for EU Relations with its Neighbours and Strategic Partners (pp. 31-33). Dahrendorf Forum.
} 
representation also at the European level makes it difficult to find agreement for a cohesive external policy and the most important institutional reforms are postponed. Considering the results of the latest elections, it is highly probable that the EP elections are going to somehow change the balance of power within the European Union: the fact that the Eurosceptic parties are making ground in such pivotal countries as Italy and France is going to affect the decisionmaking process at the EU level. Even if, according to the current polls, it is not likely that the populist parties are going to obtain the majority in the EP, they are supposed to increase their electoral performance by at least $8 \%$, gaining in this way a pivotal position in the EU decision-making processes. In the limbo, nothing changes: even though war is avoided, it is visible that the priority and attitudes in the international arena are rapidly changing.

An open conflict with Russia has to be avoided, but also an open alliance would be detrimental for the credibility of the political institutions. The ruling elites have started playing a very difficult game, where the hard task of finding an equilibrium with the autocratic Moscow is vital, also in order to keep the populists quiet. Russia remains the main energy source of many EU countries which decide, in order to avoid "cold winters", to turn a blind eye to the failure of the Minsk agreements and conflict resolutions in the post-Soviet space. Europe allows the formation of another frozen conflict near its border, while the Baltic countries look at the developments with growing concern. Eventually, "compromise is more desirable than a win-lose outcome. But in the present case, there is no compromise without at least some losers" 32 .

Meanwhile, Russia keeps in its hand the destiny of the post-Soviet space: the de facto states are destabilized enough to prevent any further opening to the West and the spectre of Crimea keeps the countries with Russian minorities in line. Despite this Cold War revival, the resilience of NATO and EU prevents open conflicts and somehow grants the security of the Baltic States, even though the political debate in the region is focused on the Russian threat. In this worrisome scenario, the central issue will be "the systemic incompatibility between a semi-authoritarian Russia bent on sovereignty hard power, and regaining part of its regional and global influence and the EU integration machine"33.

\footnotetext{
${ }^{32}$ Fert-Malka, M. (2015). Future of Russia - Scenarios for Peace and Conflict. Scenario Magazine, May2015.

${ }^{33}$ Medvedev, S., (2008) The Stalemate in EU-Russia Relations: Between Sovereignty and Europeanization. In: T. Hopf (Ed.), Russia’s European Choice. New York: Palgrave Macmillan, pp. 215-232.
} 


\section{Conclusions}

The far-right leaders welcomed the result of the European elections as the beginning of a new era. But despite the good results they achieved in some countries such as Italy and France, another interesting political force is rising within the EU: the Green and the pro-EU forces also did well, somehow containing the populist wave. At the same time, those forces showed very different positions in pivotal issues such as migration, proving that when in charge, they are not able to propose and put into action a common international reaction. Anyway, one of the features of the last EU elections has been the perception of Russian meddling as a security threat: the attempts to spread fake news, disinformation and fomenting social fears has been widely reported by the EU organizations and by the media, curbing the effective impact on the democratic process. At the same time, the hidden relations between Russian representatives and far-right MEPs have been disclosed (e.g. Italian Russiagate involving the League party for supposed financial agreements on oil), causing a huge reaction not only at the political level, but also among public opinion. In Austria, the FPÖ leader Strache was forced to leave as a consequence of the leak of a video where he was caught exchanging contracts for Russian support.

The electoral successes of the populist parties are far from being over. In the last European elections they were able not only to gain almost one-third of the seats in the European parliament, but to become the first political force in some countries, such as in Italy. It can be said that although the collaboration between Putin and the populists may be ephemeral and transitory, it has already laid the foundations for a more fruitful understanding. Russia's importance as an economic and political partner will grow as its friendly political forces grow, and their mutual sympathy will stand until there are reciprocal gains.

July 2019 